Pak. J. Agri., Agril. Engg., Vet. Sci., 2021, 37 (2): 79-86

ISSN: 1023-1072 (Print), ISSN: 2663-7863 (Online)

https://doi.org/10.47432/2021.37.2.2

\title{
IMPACT OF DIFFERENT LEVELS OF BULK DENSITIES COMBINATION ON YIELD AND YIELD COMPONENTS OF WHEAT (TRITICUM AESTIVUM L.)
}

\author{
M. S. Sabir ${ }^{1}$, M. K. Khattak, I. U. Haq, M. Hanif and S. Amjad \\ ${ }^{1}$ Department of Agricultural Mechanization and Renewable Energy Technologies, \\ The University of Agriculture, Peshawar, Pakistan \\ ABSTRACT
}

\begin{abstract}
An experiment was conducted on the impact of different levels of bulk densities combination on yield and yield components of wheat. Three bulk density levels $1.00-1.30$ (A) $\mathrm{g} \mathrm{cm}^{-3}, 1.30-1.60$ (B) g cm and 1.60-1.90 (C) $\mathrm{g} \mathrm{cm}^{-3}$ with three different depths $(0-15,16-30$ and $31-45 \mathrm{~cm})$ were used in the experiment using silt loam soil (Pedocals). The total treatments were 27 in the experiment with three replications. The experimental design was completely randomized design (CRD). The treatment means were checked at the confidence level of $95 \%$ of probability. The soil $0-45 \mathrm{~cm}$ deep was shifted from the field (no-till) to the net house and was act as control. The results showed that the number of tillers plant $^{-1}$, number of leaves plant ${ }^{-1}$ and thousand grain yield were non-significantly affected by all the treatments while number of seed emerged, root length, dry root weight, plant height, grain yield, biological yield and harvest index were significantly influenced by various treatments. The highest number of seed germinated (8.00) was found in the treatment BBB $\left(1.30-1.60 \mathrm{~g} \mathrm{~cm}^{-3}\right.$ in $0-15 \mathrm{~cm}, 15-30$ $\mathrm{cm}, 30-45 \mathrm{~cm}$ soil depth), BAB $\left(1.30-1.60 \mathrm{~g} \mathrm{~cm}^{-3}\right.$ in $0-15 \mathrm{~cm}, 1.00-1.30 \mathrm{~g} \mathrm{~cm}^{-3}$ in $15-30 \mathrm{~cm}$ and $1.30-$ $1.60 \mathrm{~g} \mathrm{~cm}^{-3}$ in $30-45 \mathrm{~cm}$ soil depth) and BCB $\left(1.30-1.60 \mathrm{~g} \mathrm{~cm}^{-3}\right.$ in $0-15 \mathrm{~cm}, 1.60-1.90 \mathrm{~g} \mathrm{~cm}^{-3}$ in $15-30$ $\mathrm{cm}$ and $1.30-1.60 \mathrm{~g} \mathrm{~cm}^{-3}$ in $30-45 \mathrm{~cm}$ ) while the lowest number of seed emerged (3.6) was found in AAA $\left(1.00-1.30 \mathrm{~g} \mathrm{~cm}^{-3}\right.$ in $0-15 \mathrm{~cm}, 15-30 \mathrm{~cm}$ and $30-45 \mathrm{~cm}$ soil depth), ACA $\left(1.00-1.30 \mathrm{~g} \mathrm{~cm}^{-3}\right.$ in $0-15$ $\mathrm{cm}, 1.60-1.90 \mathrm{~g} \mathrm{~cm}^{-3}$ in $15-30 \mathrm{~cm}$ and $1.00-1.30 \mathrm{~g} \mathrm{~cm}^{-3}$ in $30-45 \mathrm{~cm}$ soil depth) and CAC (1.60-1.90 g $\mathrm{cm}^{-3}$ in $0-15 \mathrm{~cm}, 1.00-1.30 \mathrm{~g} \mathrm{~cm}^{-3}$ in $15-30 \mathrm{~cm}$ and $1.60-1.90 \mathrm{~g} \mathrm{~cm}^{-3}$ in $30-45 \mathrm{~cm}$ soil depth). The highest root length $(13.12 \mathrm{~cm})$ was found in the treatment AAA while the lowest root length $(10.05 \mathrm{~cm})$ was found in CAC. The highest dry root weight $(5.67 \mathrm{~g})$ was found in the treatment ABA while the lowest dry root weight $(4.79 \mathrm{~g})$ was found in control treatment. The highest plant height $(42.67 \mathrm{~cm})$ was found in the treatment of BBA while the lowest plant height $(29.67 \mathrm{~cm})$ was found in control. The highest biological yield (12.1 metric ton $\mathrm{ha}^{-1}$ ) was found in the treatment ABA while the lowest biological yield $\left(6.8\right.$ metric ton ha $\left.{ }^{-1}\right)$ was found in control. The highest grain yield (4.4 metric ton ha $\left.{ }^{-1}\right)$ was found by $A B B$ while the lowest $\left(2.7\right.$ metric ton ha $^{-1}$ ) was found in the control. The highest harvest index $(39.79 \%)$ was found in the control while the lowest harvest index $(34.54 \%)$ was found in CCA. The experiment showed that increasing bulk density above $1.60 \mathrm{~g} \mathrm{~cm}^{-3}$ resulted in decreasing the yield and yield component of the winter wheat. The number of seed emerged, root length, dry root weight, plant height, grain yield, biological yield and harvest index of wheat were significantly affected by soil bulk density in various depths.
\end{abstract}

Keywords: bulk density, irrigation, pots, seed germination

\section{INTRODUCTION}

Wheat is one of the most important cereal crops. It has more protein and fiber content and it is grown mostly across the globe. Wheat is grown on nearly 10.12 million ha in the Indo-Pak region (IPR) of South Asia. It is growing on 9208 million acres in Pakistan with an average production of 6-7 tons per hectare. It adds about $13 \%$ to agriculture and $2.88 \%$ to the GDP of the country (Majeed et al., 2015). Crop production of wheat

"Corresponding author: saqlainsabir369@gmail.com depends on the type of soil, physical and chemical properties of soil, and biological factors (Michal, 2014).

Soil is a compound medium, but for easiness, it is the combination of organic and inorganic particle and pore spaces. Pore spaces allow air and water movement and moisture storage in the soil. Compaction squeezes the soil and since solids do not compress, so pore space are reduced or wheel truck run by machine in a field is an example of signals of soil compaction (Bahrani et al., 2017). 
Pak. J. Agri., Agril. Engg., Vet. Sci., 2021, 37 (2)

In plain areas, the soil have a coarse texture, reduced structure, and fertility content $>1.0 \%$ (Majeed et al., 2015) and these three factors combine to cause severe water stress and limited yield in sandy soils with low water holding capacity, short periods of drought, shallow subsurface hard and structure-less rootrestricting layers. The subsurface hard layer can restrict roots to the surface $\mathrm{Ab}$ horizon (Florian et al., 2019).

During the dehydration of buried roots, narrow waterways establish in the hard soil surface and subsurface. The process leads to enhance infiltration rate of soil (Gentili et al., 2018). Similarly, deep tilling helps in decomposing the buried crop and exploits the alleviation in the hard soil surfaces. The exclusion of dense sheets with no inversion tillage in addition facilitates roots to spread over better soil capacity to get hold of nutrients and moisture, whereas the harvesting scum stays uninterrupted on the soil surface $(\mathrm{He}$ et al., 2016).

Winter cover crop, such as rye (Secale cereale L.) and wheat (Triticum aestivam L.), merged with the cash crop excesses make best use of residue creation on the soil surface and defend the soil from wearing away during the rainy months when rainfall beats evapotranspiration and rigorous overflow happens. Cover crop residue joined with cash crop residue perks up water management for cotton by dropping soil water evaporation an infiltration of irrigation and rainfall (Amanullah et al., 2015).

In current farming, soil compaction is a most important reason of low downing yield and growth of crops. Repeated and irregular cultural processes by intense implements typically a source of soil compaction. Soil compaction roots adverse transformation in soil properties (Inal et al., 2015). The reduced soil conditions, because of compaction, slow down development of root and shoot, resulting in squeeze yields. When a clay loam soil is compacted to a density of 1.48 $\mathrm{g} \mathrm{cm}^{-3}$ from an earlier density of $1.22 \mathrm{~g} \mathrm{~cm}^{-3}$, shrunk the grain and straw yields of wheat by $12-23$ and 9-20\%, respectively (Kamkar, 2014). Ishaq et al. (2001) examined 38 and 9\% reductions in grain and straw yields, respectively, of wheat, when the soil was compressed to a bulk density of $1.93 \mathrm{~g} \mathrm{~cm}^{-3}$ from an original bulk density of $1.65 \mathrm{~g} \mathrm{~cm}^{-3}$. Compaction not only decreases pore volume, but amends the pore geometry. Therefore, soil compactions transform soil structure and impinge on a collection of significant ecological tasks (Khurshid et al., 2017). It may well persuade privileged flow in macro-pores which has been exposed to assist conveys of or else inert contaminants such as phosphorus and pesticides to getting water bodies (Al-Masmoudi et al., 2019). In high compacted soil, for root penetration the crop applies greater force than the shear strength of compacted soil. Variation in soil physical characteristic i.e. bulk density is an aspect based by compaction which concerns root expansion. Soil compaction is able to persuade the attentiveness and faction of air which possibly will answer in a limited root progress (Shah et al., 2017).

Guan et al. (2014) evaluated that solitary functions of plant roots is to sustain the contribution of nutrients and water to the plant while the yield is reliant to the root expansion, resolving the competency for nutrient and water. The impending of plants to gain water and mineral is relayed to their aptitude to extend roots; temporarily compaction limits root expansion and plant contact to nutrients and water.

Deprived root growth caused by intense and inadequately aerated soil can lessen crop yield (Peter et al., 2014), nutrient use efficiency and thus stimulate escaping of soil nitrogen. Soil compaction is for that reason a vital reason of a lot of ecological and agronomic problems which have considerable contacts with natural services and expenditures to humanity and the agricultural industry.

Soil compaction restricted agronomic characteristics of crops i.e. seed emergence, root growth, plant morphology and soil properties (Penetration resistance, porosity, infiltration rate, nutrients availability and aeration). These relationships had been studied and documented extensively by different researchers. However, combination of bulk densities of soil with different depths is still a problem in Pakistan. The aim of this study was to find out the yield of wheat in different combinations of bulk densities at different depths. The objective of this experiment was to evaluate the influence of various bulk densities combination on the wheat growth and production.

\section{MATERIALS AND METHODS Experimental site}

The experiment was conducted on the impact of different levels of bulk densities combination on yield and yield component of wheat in net house in the department of Agricultural Mechanization 
and Renewable Energy Technologies, the University of Agriculture Peshawar. The University of Agriculture, Peshawar located at $34^{\circ} 03^{\prime} \mathrm{N}$ and longitude of $71^{\circ} 62^{\prime} \mathrm{E}$. The Soil was collected from the University Research Farm, the University of Agriculture Peshawar. Table 1 show the soil description used in the experiment. The dried soil at $70{ }^{\circ} \mathrm{C}$ was grounded using mesh size of $0.02 \mathrm{~mm}$. pH of soil was measured in a suspension of soil and water (1:5) after half an hour of stirring using $\mathrm{pH}$ meter. The $\mathrm{P}$ and $\mathrm{K}$ in the soil were estimated by the procedure described by Sher et al. (2018) using atomic absorption spectrometer and flame photometer. The soil $\mathrm{N}$ was measured by using kjeldhal procedure. The soil electrical conductivity was measured by EC meter as suggested by Sher et al. (2018). The net house environmental conditions are shown in Table 2. The soil 0-45 $\mathrm{cm}$ deep was shifted from the field (no-till) to the net house and was act as control.

Table 1. Soil description used in the research

\begin{tabular}{|l|l|l|l|l|}
\hline Texture & $\mathbf{p H}$ & $\begin{array}{l}\text { EC } \\
(\mathbf{d S} \\
\left.\mathbf{m}^{-1}\right)\end{array}$ & NPK $\mathbf{( m g ~ k g ~}^{-1}$ ) & $\begin{array}{l}\text { Organic } \\
\text { matter (\%) }\end{array}$ \\
\hline $\begin{array}{l}\text { Silt loam } \\
\text { (Pedocals) }\end{array}$ & 8.00 & 0.34 & $0.02,14.2,180$ & 0.43 \\
\hline
\end{tabular}

\section{Equipments used in the Experiment}

The material and equipment used were:

- Shovel

- $\quad$ Electronic Balance

- Soil, Water, wheat seeds and fertilizer etc. Pots were constructed from iron can of internal diameter $18 \mathrm{~cm}$.

\section{Procedure}

By varying the bulk density level, three different bulk density levels were created for each subsection of the pot separately (i.e. $0-15.24$, 15.24-30.48 and 30.48-45.72 cm depths) and recommended doses of fertilizer for wheat was mixed with the soil. For the different level of bulk densities, the soil was weighed by electronic balance $(5.44 \mathrm{~kg}, 6.92 \mathrm{~kg}, 8.40 \mathrm{~kg}$ of soil to establish $1.00 \mathrm{~g} \mathrm{~cm}^{-3}, 1.30 \mathrm{~g} \mathrm{~cm}^{-3}$ and $1.60 \mathrm{~g} \mathrm{~cm}^{-}$ ${ }^{3}$ soil bulk densities respectively) and then the soil was poured in each subsection of the pot (20 cm diameter and $15.24 \mathrm{~cm}$ height for each pot). The weighed soil was prevented from compaction in each pot. Thus bulk density of soil was maintained in each pot.

After that, all three subsections of the pot were joined together by solution tape and make one whole pot. By the creation of these various combination levels of bulk densities, a little bit changes may occurred in each level of combination; however, it was not exceeded the required range of bulk density because artificial pressure was kept constant on each type of bulk density. Winter wheat was sown at $15^{\text {th }}$ November 2019 @ 8 number of seeds in each pot. Moisture content level was kept constant in each wheat growing stage (Table 2) in the whole experiment in all the treatments throughout the growing season by using soil moisture sensor. In each pot, seeds were planted at $2 \mathrm{~cm}$ depth and then pots were placed in the department of Agricultural Mechanization. Cultural practices were kept uniform, weeding was done manually. The pot was irrigated with a proper amount of water in each developmental stage according to the water requirement for wheat as shown below in the table 2 . In case of rainfall, the required amount of water should be found by the difference between the rainfall and water requirement in each individual stage of wheat growth.

Required irrigation $(\mathrm{mm})=$ water requirement $(\mathrm{mm})$ - rainfall $(\mathrm{mm})$ Eq. 3.1

Table 2. Irrigated water, net house temperature, relative humidity and light intensity during experiment

\begin{tabular}{|l|l|l|l|l|}
\hline Stage & $\begin{array}{l}\text { Irrigated } \\
\text { water }\end{array}$ & $\begin{array}{l}\text { Net house } \\
\text { temperature } \\
\text { (Max-Min) }\end{array}$ & $\begin{array}{l}\text { Relative } \\
\text { humidity } \\
\%\end{array}$ & $\begin{array}{l}\text { Light } \\
\text { intensity } \\
\text { ft/cd }\end{array}$ \\
\hline Before tillering & $\begin{array}{l}\text { less than } \\
1 \mathrm{~mm}\end{array}$ & $12-15^{\circ} \mathrm{C}$ & $60-65 \%$ & $1200-1300$ \\
\hline Tillering & $3-4 \mathrm{~mm}$ & $16-20^{\circ} \mathrm{C}$ & $60-65 \%$ & $1200-1300$ \\
\hline Booting stage & $4-5 \mathrm{~mm}$ & $21-26^{\circ} \mathrm{C}$ & $65-70 \%$ & $1300-1400$ \\
\hline $\begin{array}{l}\text { Heading and } \\
\text { flowering }\end{array}$ & $\begin{array}{l}5.5-6.5 \\
\mathrm{~mm}\end{array}$ & $27-32^{\circ} \mathrm{C}$ & $70-75 \%$ & $1400-1500$ \\
\hline Ripening stage & $\begin{array}{l}\text { less than } \\
4 \mathrm{~mm}\end{array}$ & $33-41^{\circ} \mathrm{C}$ & $45-50 \%$ & $1500-1550$ \\
\hline
\end{tabular}

\section{Experimental design}

A complete randomize design (CRD) was used in the experiment. The treatment is shown in the Table 3.

Table 3. Bulk densities and depth of soil in the research

\begin{tabular}{|l|l|l|l|}
\hline $\begin{array}{l}\text { Bulk } \\
\text { density }\end{array}$ & $\begin{array}{l}\text { Bulk density } \\
\text { Range }\end{array}$ & Depth level & $\begin{array}{l}\text { Depth level } \\
\text { Range }\end{array}$ \\
\hline A & $1.00-1.30 \mathrm{~g} \mathrm{~cm}^{-3}$ & Depth 1 & $0-15 \mathrm{~cm}$ \\
\hline B & $1.30-1.60 \mathrm{~g} \mathrm{~cm}^{-3}$ & Depth 2 & $15-30 \mathrm{~cm}$ \\
\hline $\mathrm{C}$ & $1.60-1.90 \mathrm{~g} \mathrm{~cm}^{-3}$ & Depth 3 & $30-45 \mathrm{~cm}$ \\
\hline
\end{tabular}

The combination of the above mentioned three different levels of bulk densities were considered individually as well as combined with each other in the above mentioned three depths and treatments were made from their combination for conducting the experiment. There were a total of 27 different bulk density combinations and all these 27 combinations mean individual 
treatment. Descriptions of treatments are shown in Table 4. Each combination/treatment was replicated 3 times. There was one control used in each replication. Hence, a total of 84 plots were used in the experiment.

Table 4. Description of treatments

\begin{tabular}{|l|l|l|l|l|l|}
\hline S\#. & $\boldsymbol{T}$ & S\#. & $\boldsymbol{T}$ & S\#. & $\boldsymbol{T}$ \\
\hline 1 & AAA & 10 & BBB & 19 & CCC \\
\hline 2 & AAB & 11 & BBA & 20 & CCA \\
\hline 3 & ABA & 12 & BAB & 21 & CAC \\
\hline 4 & ABB & 13 & BAA & 22 & CAA \\
\hline 5 & AAC & 14 & BBC & 23 & CCB \\
\hline 6 & ACA & 15 & BCB & 24 & CBC \\
\hline 7 & ACC & 16 & BCC & 25 & CBB \\
\hline 8 & ABC & 17 & BAC & 26 & CAB \\
\hline 9 & ACB & 18 & BCA & 27 & CBA \\
\hline
\end{tabular}

WT represents treatment, $A=1.00-1.30 \mathrm{~g} \mathrm{~cm}^{-3}, B=1.30-1.60 \mathrm{~g} \mathrm{~cm}^{-3}$, $\mathrm{C}=1.60-1.90 \mathrm{~g} \mathrm{~cm}^{-3}$

\section{Data collection}

\section{Number of seed emerged}

Data was recorded on 5 plants from dates of sowing till $50 \%$ germination from all treatment in each replication and then their average was noted.

\section{Number of tiller}

Number of tiller was recorded on 5 plants after germination from all the treatment in each replication and then their average was noted.

\section{Root depth (cm)}

Root depth data was collected after the harvesting of the crop in each subsection of pot. Soil was removed by using different size of sieves and also by washing of water carefully. So that soil and crop residue may be separated from the roots.

\section{Dry root weight (g)}

Dry weight of root data was taken after harvesting of 5 plants from all the treatment in each replication. The roots were dried at $55^{\circ} \mathrm{C}$ in oven.

\section{Plant height (cm)}

Plant height data were recorded on 5 plants till maturity stage in each week from all the treatment in each replication in their average was taken.

\section{Plant leaves}

Data regarding no of leaves were recorded by counting leaves in randomly selected plants of all treatments and replication then average was taken.

\section{0 -Grain yield $(\mathrm{g})$}

The mass of thousand grains were selected randomly from each pot and then their mass was measured by using electronic scale.

\section{Biological yield $\left(\mathrm{g} \mathrm{pot}^{-1}\right)$}

The plants in each pot were harvested separately. Then the plants were dried by open sun. The biological yield of plant was measured after drying the wheat crop by using electronic scale.

\section{Grain yield $\left(\mathrm{g} \mathrm{pot}^{-1}\right)$}

The plants in each pot were harvested separately. Then the plants were dried by open sun. The grain yield of plants was measured after drying the wheat crop by using electronic scale.

\section{Harvest index (\%)}

The harvest index was analyzed by dividing grain yield $\left(\mathrm{g} \mathrm{pot}^{-1}\right)$ to the biological yield $(\mathrm{g}$ $\left.\operatorname{pot}^{-1}\right)$.

$$
\text { Harvest index }=\frac{\text { Grain yield }}{\text { Biological yield }} \times 100
$$

\section{Statistical analysis}

The statistical package SPSS (SPSS version 2016) was used for the analysis of data at $95 \%$ confidence level. This analysis of variance and treatments means were tested by LSD.

\section{RESULTS AND DISCUSSION}

The pot experiment was conducted on different bulk densities combination on the wheat growth and yield. The result showed that the treatment had no significant effect on the number of leaves, number of tillers, thousand grain yield while the significantly affected parameters is discussed below.

\section{Number of seed emerged}

Data recording seed germination is shown in Figure 1. The result showed that seed germination in wheat was significantly affected by various bulk densities. However the highest number of seed emerged (8.00) was found in the treatment CAA while the lowest number of seed emerged (4.7) was found in control. It revealed that germination of wheat seeds was unequally influenced by various treatments.

These result are similar to those of Adeel et al. (2019) who reported that bulk densities showed significant differences on emergence of wheat seed, but dissimilar to those of Bahrani et 
al. (2017) who found no effect of bulk densities on germination. The reason may be that surface layer of soil was broken equally by various treatment which provided uniform and aerated seedbed for germination of wheat seeds.

The reason is that the bulk density either too low or too high may affect the germination of seed because too low bulk density slows down with irrigation which affects the germination of seed. Also, when too high bulk density i.e. above 1.60 , seed may not easily germinate due to high compaction.

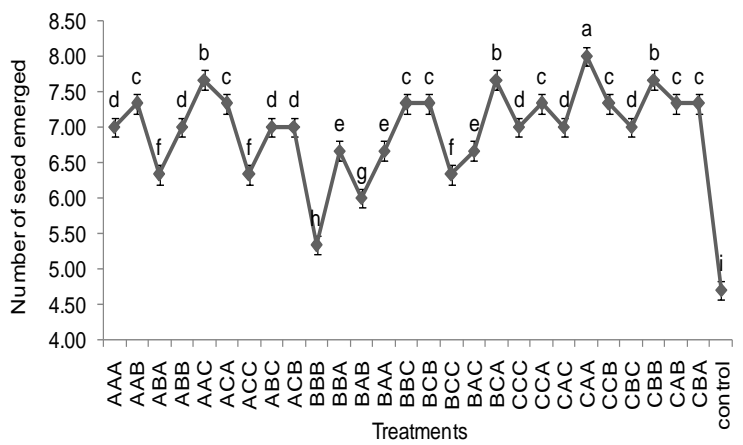

Figure 1. Number of wheat seed emerged as affected by combination of various bulk densities. The abbreviations in the graph have been described in Table 3 .

\section{Root length (cm)}

Data recording root length is shown in Figure 2. The result showed that root length of wheat was significantly affected by various bulk densities combination treatment. The highest mean root length $(11.43 \mathrm{~cm})$ was found in the treatment $A B A$ while the lowest root length $(10.32 \mathrm{~cm})$ was found in AAA.

These findings are supported by Kashif et al. (2018), who reported that the roots penetrated 18 to $20 \mathrm{~cm}$ deeper in the loose soil while roots penetrated 15 to $1 \mathrm{~cm}$ in the compacted soil. A well prepare, seedbed essential for growing smaller seed. It not only furnishes better conditions for water absorption by the seed but also gives the young roots better soil contact and thus promotes their efficiency in absorbing water and nutrients. A loose crumbly surface soil however, is best for retaining the water longer for roots. Elongation of roots, under favorable conditions, is very rapid sometimes and growth rate of over half an inch a day is maintained for 60 to 70 days in the primary roots system of winter wheat. Crops planted early during favorable for growth form a secondary root system, which fill the surface 30 to $45 \mathrm{~cm}$ of soil while the primary root extended well into the 90 and $120 \mathrm{~cm}$. The mature root system has a working level of 105 to $120 \mathrm{~cm}$ in a maximum depth of 150 to $210 \mathrm{~cm}$.

The quantification and prediction of soil compaction has a relation with the plant growth and development. The soil organic matter and water content are the major factors affecting soil compaction. It affects physical, chemical and biological properties of soil. It induced retardation in root and shoot growth rate, low germination rate and higher mortality rate than the non-compacted soil (Nawaz et al., 2013).

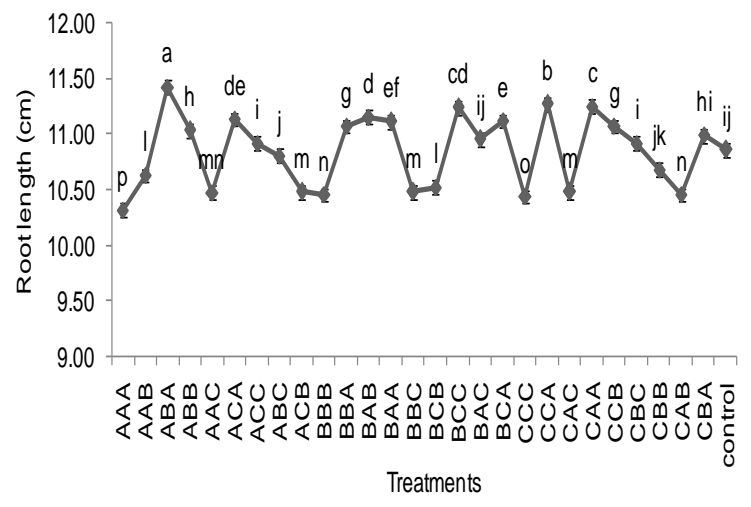

Figure 2. Root length of wheat as affected by various combinations of bulk densities. The abbreviations in the graph have been described in Table 3 .

\section{Dry root weight $(g)$}

Data recording dry root weight is shown in Figure 3. The result showed that the dry root weight was significantly affected by the treatments. The highest mean dry root weight $(0.90 \mathrm{~g})$ was found in the treatment ABA while the lowest dry root weight $(0.53 \mathrm{~g})$ was found in control.

Mohsin et al. (2019) stated that increasing bulk density might have positive consequences on root biomass of maize. Almost certainly, compaction may have persuaded dynamic root proliferation and enlargement as obvious in more and comparatively wider roots in soil samples accumulated from the compacted sites. The considerable positive correlation between root biomass and bulk density appears to support this observation. Alike correlation between root biomass of lupine and oilseed rape with soil bulk density has been found. Djanaguiraman et al. (2019) examined additional root enlargement in the top layer of compacted soil with about $70 \%$ of the total root length focused in the top $12 \mathrm{~cm}$ depth contrasted to around $40 \%$ in un-compacted soils. In this study, about $80 \%$ of total dry root biomass of maize was focused in the range of $0-50 \mathrm{~cm}$ depth. 


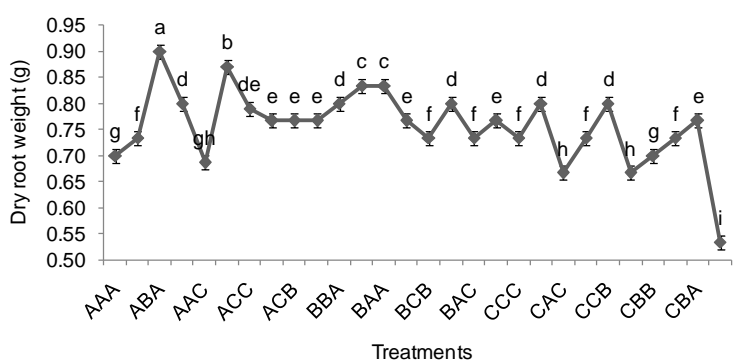

Figure 3. Dry root weight $(\mathrm{g})$ of wheat as affected by various combinations of bulk densities. The abbreviations in the graph have been described in Table 3.

\section{Plant height (cm)}

Data recording plant height is shown in Figure 4. The result showed that the plant height was significantly affected by the treatments. It revealed that plant height of wheat was unequally influenced by various treatments. The highest mean plant height $(42.67 \mathrm{~cm})$ was found in the treatment ACA while the lowest plant height $(29.67 \mathrm{~cm})$ was found in control. All the treatments showed better result in plant height except AAA, AAB, AAC, CAC, CBA and control had a less than $40.00 \mathrm{~cm}$ plant height.

The result showed that the plant height was enhanced in bulk densities combination of 1.3$1.6 \mathrm{~g} \mathrm{~cm}^{-3}, 1.3-1.6 \mathrm{~g} \mathrm{~cm}^{-3}$ and $1-1.3 \mathrm{~g} \mathrm{~cm}^{-3}$ in the depth combination of $0-15 \mathrm{~cm}, 16-30 \mathrm{~cm}$ and $31-$ $45 \mathrm{~cm}$ respectively. The result was supported by Obafemi and Yessoufou (2019). They stated that the plant height of weight was significantly affected by the soil bulk density. Increasing bulk density decrease the porosity in the soil aggregates result in retarding growth.

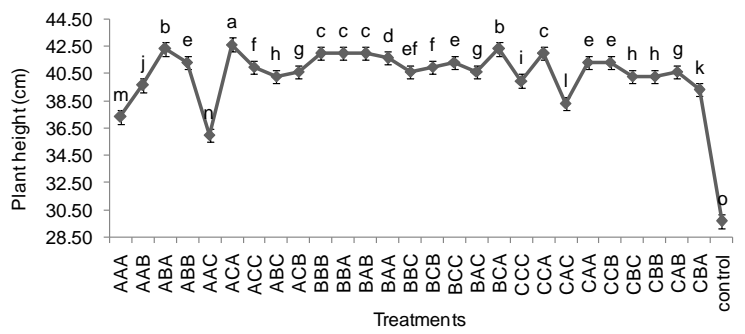

Figure 4. Plant height of wheat as affected by various combinations of bulk densities. The abbreviations in the graph have been described in Table 3.

\section{Biological yield $\left(\mathrm{g} \mathrm{pot}^{-1}\right)$}

Data recording biological yield is shown in Figure 5. The result showed that biological yield wheat was significantly affected by various bulk densities combination. It revealed that biological yield of wheat seeds was equally influenced by various bulk density treatments. The highest mean biological yield (144 $\left.\mathrm{g} \mathrm{pot}^{-1}\right)$ was found in the treatment BCA followed by CCA (143) while the lowest biological yield (118 $\left.\mathrm{g} \mathrm{pot}^{-1}\right)$ was found in control. All the treatments achieved more than $130 \mathrm{~g} \mathrm{pot}^{-1}$ biological yield except control.

The result showed that increasing bulk density of soil in the root zone decrease the biological yield significantly. The result coincides with Głąb (2011). They stated that increasing compaction of soil reduces the nutrient extraction from the soil, results in decreasing biological yield of alfalfa.

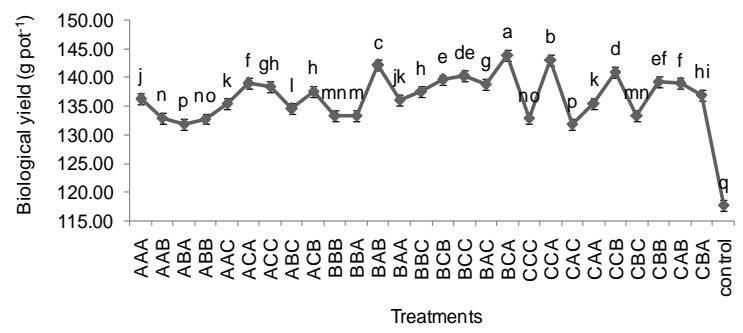

Figure 5. Biological yield $\left(\mathrm{g} \mathrm{pot}^{-1}\right)$ of wheat as affected by various combinations of bulk densities. The abbreviations in the graph have been described in Table 3 .

\section{Grain yield $\left(\mathrm{g} \mathrm{pot}^{-1}\right)$}

Data recording grain yield is shown in Figure 6. The result showed that grain yield of wheat was significantly affected by various bulk densities. It revealed that grain yield of wheat seeds was influenced by various treatments. The result showed that the grain yield was significantly concerned with the treatments applied. The highest grain yield $\left(49.8 \mathrm{~g} \mathrm{pot}^{-1}\right)$ was established by $B A B$ and BCA while the lowest $\left(46.8 \mathrm{~g} \mathrm{pot}^{-1}\right)$ was found in the control. All the treatment means achieve greater grain yield than $48 \mathrm{~g} \mathrm{pot}^{-}$ 1 yield except control. The result showed that increasing bulk density in the depth above 16 $\mathrm{cm}$, decrease the grain yield. The result is according to the Obafemi and Yessoufou (2019). They stated that increasing bulk density above $1.5 \mathrm{~g} \mathrm{~cm}^{-3}$ reduces the grain yield up to $18 \%$.

\section{Harvest index (\%)}

Data recording harvest index is shown in Figure 7. The result showed that harvest index of wheat was significantly affected by various bulk densities combination. It revealed that harvest index of wheat was influenced by various treatments.

The highest mean harvest index (40\%) was found in the control followed by $38 \%$ in $A B A$ while the lowest harvest index $(34.6 \%)$ was found in BCA. The result showed that reducing bulk density increases the harvest index (\%). 
The result is similar to the Obafemi and Yessoufou (2019). They showed that increasing bulk density decrease the harvest index of the maize.

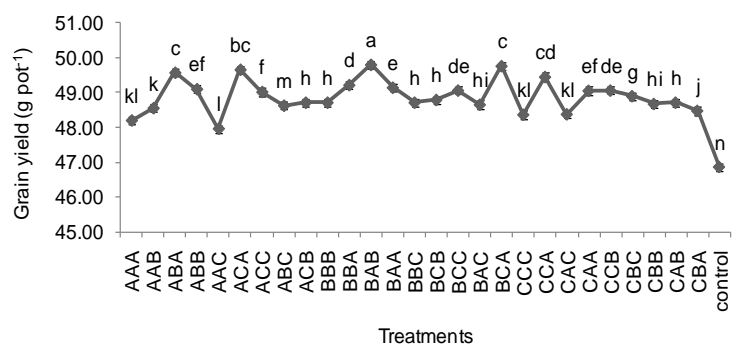

Figure 6. Grain yield $\left(g \operatorname{pot}^{-1}\right)$ of wheat as affected by various combinations of bulk densities. The abbreviations in the graph have been described in Table 3.

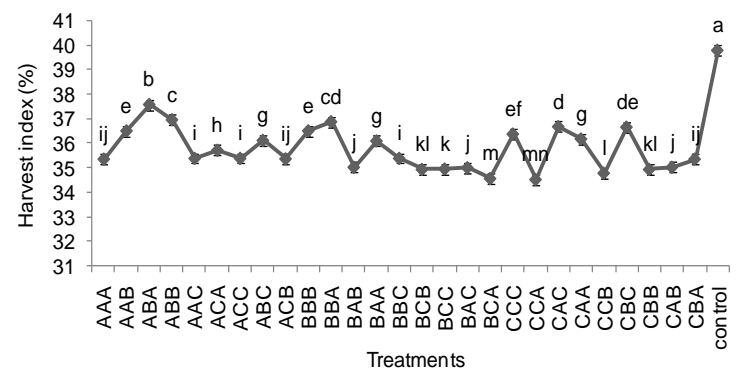

Figure 7. Harvest index (\%) of wheat as affected by various combinations of bulk densities. The abbreviations in the graph have been described in Table 3.

\section{CONCLUSION}

The seed emergence, root length, dry root weight, plant height, grain yield, biological yield and harvest index of wheat were significantly affected by combination of various BD levels. The highest wheat seed emergence, plant height and grain yield was found in the bulk density combination of 1.3 to $1.60 \mathrm{~g} \mathrm{~cm}^{-3}$. However, highest root length, dry root weight and biological yield were shown in the combination of 1.00 to $1.3 \mathrm{gcm}^{-3}$. Increasing bulk density retards the yield and yield component of wheat in the range of $15-20 \%$.

\section{RECOMMENDATIONS}

The experiment recommended that:

Under silt loam soil $A B A, B B B, B A B$ and $B C B$ treatments may be used for better wheat growth. Further experiment may be conducted with the same treatments on corn and other crops.

\section{CONFLICT OF INTEREST}

The authors have no conflict of interest. The research had not been funded by any financial agency.

\section{AUTHOR'S CONTRIBUTION}

M. S. Sabir: Conducted the research, collected the data, writing the manuscript draft

M. K. Khattak: Supervised the research, conceptualization of the research, methodology, validation, resources

I. U. Haq: Co-supervised the research, data analysis, writing-original draft preparation

M. Hanif: Formal analysis, investigation, data collection, collection of literature

S. Amjad: Writing-review and editing, formal analysis

\section{REFERENCES}

Adeel, L., N. Khan, F. Nawaz, S. Ullah, Z. Hussain and A. R. Khan. 2019. Growth of wheat as affected by fresh and composted poultry manure, urea and beneficial microbes. Pure and Applied Biology, 8 (2): 1408-1419.

Al-Masmoudi, Y., E. A. Abdellah and I. N. Khalid. 2019. Evaluation of the Compaction of a No-Till Vertisol Field Using Methods of Cone Index and Pedo-transfer Function in Semi-arid Context of Morocco. Journal of Agricultural Science and Technology, 9: 141-150.

Amanullah, J., K. Imran, A. Jan, M. T. Jan, S. K. Khalil, Z. Shah and M. Afzal. 2015. Compost and Nitrogen Management Influence Productivity of Spring Maize (Zea mays L.) under Deep and Conventional Tillage Systems in Semi-arid Regions. Communication in Soil Science and Plant Analysis, 46 (12): 1566-1578.

Bahrani, M., M. Davoodi and S. Kazemeini. 2017. Wheat Yield as Influenced by Nitrogen Rates, Sources and Tillage Systems. International Journal of Plant and Soil Science, 20 (1): 1-8.

Djanaguiraman, M., P. V. V. Prasad, J. Kumari, and Z. Rengel. 2019. Root length and root lipid composition contribute to drought tolerance of winter and spring wheat. Plant and Soil, 439 (1): 57-73.

Florian, U., D. Avelar, P. Hobson, L. Penha, T. Dias, C. Maguas and C. Cruz. 2019. Sustainable urban agriculture using compost and an open-pollinated maize variety. Journal of Cleaner Production, 212: 622629.

Gentili, R., R. Ambrosini, C. Montagnani, S. Caronni and S. Citterio. 2018. Effect of Soil $\mathrm{pH}$ on the Growth, Reproductive Investment and Pollen Allergenicity of Ambrosia 
Pak. J. Agri., Agril. Engg., Vet. Sci., 2021, 37 (2)

artemisiifolia L. Frontier Plant Science, 9: 1335-1338.

Głąb, T. 2011. Effect of soil compaction on root system morphology and productivity of Alfalfa (Medicago sativa L.) Poland Journal of Environmental Studies, 20 (6): 14731480.

Guan, P., R. Wang, P. Nacry, G. Breton, S. A. Kay, J. L. Pruneda-Paz, A. Davani and N. M. Crawford. 2014. Nitrate foraging by Arabidopsis roots is mediated by the transcription factor TCP20 through the systemic signaling pathway. Proceedings of the National Academy of Sciences, 111 (42): 15267-15272.

He, G., Z. Wang, F. Li, J. Dai, Q. Li, C. Xue, H. Cao, S. Wang and S. S. Malhi. 2016. Soil water storage and winter wheat productivity affected by soil surface management and precipitation in dry land of the Loess Plateau, China. Agricultural Water Management, 171: 1-9.

Inal, A., A. Gunes, O. Sahin, M. B. Taskin and E. C. Kaya. 2015. Impacts of biochar and processed poultry manure, applied to a calcareous soil, on the growth of bean and maize. Soil Use Management, 31 (1): 106-113.

Ishaq, M., M. Ibrahim, A. Hassan, M. Saeed and R. Lald. 2001. Subsoil compaction effects on crops in Punjab, Pakistan: II. Root growth and nutrient uptake of wheat and sorghum. Soil and Tillage Research, 60 (3-4): 101-109.

Kamkar, B. 2014. The effect of crop residues on soil nitrogen dynamics and wheat yield. Advances Plants and Agriculture Research, 1 (1): 1-7.

Kashif, M., M. Javed, S. Ullah, A. Ali and G. R. Khan. 2018. Effect of Planting Methods and Nitrogen Sources on Yield, Yield Components and N-Uptake of Spring Maize. Advance Crop Science and Technology, 6 (3): $1-5$.

Khurshid, O., A. Naureen, K. Ayaz, N. Alia, K. Abdullah, N. Sobia and S. Sehrish. 2017. Assessment of Municipal Solid Waste
Compost of different socio-economic groups of Peshawar City, Khyber Pakhtunkhwa, Pakistan. Pakistan Journal of Agricultural Research, 30 (2): 180-184.

Majeed, A., M. Atif, N. Abid, J. Shahid, A. Zahid, S.H. Syed and H. Asrar. 2015. Bed planting of wheat (Triticum aestivum L.) improves nitrogen use efficiency and grain yield compared to flat planting. Crop, 3 (2): 118-124.

Michal, L. 2014. Factors affecting soil temperature as limits of spatial interpretation and simulation of soil temperature. Acta Universitatis Palackianae OlomucensisGeography, 45 (1): 5-21.

Mohsin, M., M. A. Shakeel, S. Ullah, M. Yousaf, A. Mujtaba and M. Hussain. 2019. Influence of different tillage practices on yield of autumn planted maize. Pakistan Journal of Agricultural Research, 32 (2): 293-301.

Nawaz M. F., G. Bourrié and F. Trolard. 2013. Soil compaction impact and modeling. A review. Agronomy Sustainable Development, 33 (2): 291-309.

Obafemi, O. O. and M. A. Yessoufou. 2019. Effect of Soil Compaction on the Growth and Nutrient Uptake of Zea mays L. Sustainable Agricultural Research, 8 (2): 46-54.

Peter, R., J. Pablo and M. N. Garcia. 2014. Global maize production, utilization, and consumption. Annals of New York Academic Science, 1312 (1): 105-112.

Shah A. N., T. Mohsin, B. Shahzad, G. Yang, S. Fahad, S. Ali, M. A. Bukhari, S. A. Tung, A. Hafeez and B. Souliyanonh. 2017. Soil compaction effects on soil health and crop productivity: an over view. Environmental Science Pollution Research, 24 (11): 1005610067.

Sher, A., K. Naveed, G. Ahmad, A. Khan, M. Saeed and S. Masaud. 2018. Phenology and biomass production of wheat in response to micronutrients and nitrogen application. Sarhad Journal of Agriculture, 34 (4): 712-723.

(Received: July 18, 2021; Accepted: November 02, 2021) 